\title{
Microsatellite markers for population genetic studies of the rock firefinch, Lagonosticta sanguinodorsalis
}

\author{
Jacinta Abalaka ${ }^{1,2 *}$ \& Bengt Hansson ${ }^{2}$ \\ ${ }^{1}$ Department of Genetics, University of Pretoria, Private Bag X20, Hatfield, 0028 South Africa \\ ${ }^{2}$ Department of Biology, Lund University, 22362 Lund, Sweden
}

Received 27 September 2013. Accepted 20 May 2014

We identified the first set of microsatellites for use in the rock firefinch (Lagonosticta sanguinodorsalis). First, we tested existing passerine microsatellite loci for cross-species amplification success in a small sample of rock firefinches and identified 10 loci that were seemingly polymorphic and easy to score. Secondly, we developed and characterized three microsatellite loci de novo from the rock firefinch genome. In a larger sample of individuals from three populations, one locus initially interpreted as polymorphic was monomorphic. Among the polymorphic loci, the number of alleles ranged between 2 and 15 and the expected heterozygosity between 0.08 and 0.91 within populations. Two loci had high estimated null allele frequency in at least one population. The microsatellites amplified very well ( $80 \%$ success) in five other African finch species and each locus was confirmed as polymorphic in at least one species. We conclude that these microsatellite markers will be useful for population genetic studies in the rock firefinch and other closely related African finches.

Key words: population genetics, microsatellite, primer, Lagonosticta sanguinodorsalis.

Molecular markers have become important tools in understanding the population genetic structure, and population dynamics and colonization history of species. Among the different types of molecular markers, microsatellites (or short-sequence repeats) have been adopted as the marker of choice for detecting intra- and inter-population genetic diversity because of their high variability and abundance throughout the genome (Ellegren 2004).

The rock firefinch, Lagonosticta sanguinodorsalis, a seed-eating Estrildidae finch, was described as recently as 1998 (Payne 1998). It has a restricted range and was initially believed to be endemic to Nigeria where it is found in bushy and rocky outcrops on the Jos Plateau and its north and eastward extensions (central Nigeria), on the Mandara Mountains (northeastern Nigeria) and in Rano (northern Nigeria; Payne 1998; Wright \& Jones

*Author for correspondence. E-mail: jacinta.abalaka@biol.lu.se
2005). However, other populations were more recently discovered in Maroua and Mora in northern Cameroon (Mills 2010). The rock firefinch is socially monogamous with a sexually dimorphic plumage where adult males are more brightly coloured than adult females (Fry \& Keith 2004). Interestingly, it is the obligate host to a brood parasitic indigobird, the endemic Jos Plateau indigobird (Vidua maryae; Brandt \& Cresswell 2008).

Although the rock firefinch is listed as species of least concern (http://www.iucnredlist.org/; accessed May 2012), the species' restricted range and specific habitat requirements, and its important role in the life history of another endemic species, make it of conservation interest. Furthermore, it presently occurs in small fragmented populations and the level of movements and dispersal between subpopulations is unknown (Brandt \& Cresswell 2008; Abalaka \& Jones 2011). As a preparatory step to studying population genetic structure and gene flow in the rock firefinch, we have identified a set of polymorphic microsatellite markers. To our knowledge, no microsatellite markers have previously been reported for $L$. sanguinodorsalis. We also examined the suitability of these markers for use in five other African finches.

Our first approach in identifying usable microsatellite loci was to test 51 existing microsatellite primer pairs designed for other passerine species for cross-species amplification in the rock firefinch. Most of these primers were selected from among those that have proven to amplify successfully across a wide range of species (Simeoni et al. 2007; Dawson et al. 2010; Olano-Marin et al. 2010; Salmona et al. 2010). Initially, we tested primers on four individual rock firefinches that had been trapped using mist nets in the Amurum Forest Reserve, Central Nigeria $\left(09^{\circ} 52^{\prime} 44.75^{\prime \prime} \mathrm{N}\right.$, $\left.08^{\circ} 58^{\prime} 55.75^{\prime \prime} \mathrm{E}\right)$. DNA was extracted from a small amount of blood using a standard phenol-chloroform protocol as described in Bensch et al. (1994). The PCR mix contained 4 pmol of each primer 
$(0.4 \mu \mathrm{M}), 1 \times \mathrm{NH}_{4}$-buffer, $15 \mathrm{nmol}(1.5 \mathrm{mM}) \mathrm{MgCl}_{2}$, $2 \mathrm{nmol}(0.2 \mu \mathrm{M}) \mathrm{dNTP}, 0.5 \mathrm{U}$ AmpliTaq DNA polymerase and $10-25 \mathrm{ng}$ template DNA in $10 \mu \mathrm{l}$ reaction volume. PCRs were carried out in a GeneAmp PCR System 9700 (Applied Biosystems), and the conditions were as follows: $94^{\circ} \mathrm{C}$ for $2 \mathrm{~min}$; then 35 cycles with $94^{\circ} \mathrm{C}$ for $30 \mathrm{~s}, T_{a}$ for $30 \mathrm{~s}$, and $72^{\circ} \mathrm{C}$ for $30 \mathrm{~s}$; followed by $72^{\circ} \mathrm{C}$ for $10 \mathrm{~min}\left(T_{a}=\right.$ locus-specific annealing temperature). The fluorescent-labelled PCR-products were separated and the alleles were detected in an ABI PRISM 3730 capillary sequencer (Applied Biosystems). Ten of the 51 primer pairs tested on the four individual rock firefinces were potentially useful as they had apparently polymorphic products and seemed easy to score. The remaining primers did not amplify (four loci), were polymorphic but weak (three loci), were polymorphic but difficult to score (two loci) or monomorphic (32 loci).

Our second approach was to isolate and characterize microsatellites de novo from the rock firefinch genome to increase the number of available markers, as it is more advantageous to invest in the number of highly polymorphic markers than in the number of individuals for many research questions (Landguth et al. 2012; Takezaki \& Nei 1996).

A microsatellite-enriched library was constructed using protocol provided by Zane et al. (2002) with slight modifications following Nordström \& Hedren (2007). Genomic DNA (500 ng) of four individuals was digested with $10 \mathrm{U}$ of Bsp1431 (Fermentas) together with $1 \times$ reaction buffer (Fermentas) and $1 \mu \mathrm{g}$ Bovine Serum Albumin in a total volume of $20 \mu \mathrm{l}$. This mix was incubated for 1 hour at $37^{\circ} \mathrm{C}$ and, to deactivate the enzyme, for $20 \mathrm{~min}$ at $80^{\circ} \mathrm{C}$. Then, $5 \mu \mathrm{l}$ ligation reaction mix containing adaptors (5 $\mu \mathrm{M} ; 5^{\prime}$-GTGGTAGA CTGCGTACC-3' and 5'-GATCGGTACGCAGTCT AC- $\left.3^{\prime}\right)$, ligation buffer $(1 \times$; USB) and T4 DNA ligase (0.5 U; USB) was added to the digestion reaction and incubated for three hours at $37^{\circ} \mathrm{C}$. The digestion-ligation mix was diluted 1:10, and $10 \mu \mathrm{l}$ was PCR-amplified using the following conditions: $0.5 \mu \mathrm{M}$ specific primer (5'-GACTGCGTA CCGATC-3'), $2 \mathrm{mM} \mathrm{MgCl}{ }_{2}, 0.2 \mathrm{mM}$ dNTPs, $1 \times$ polymerase buffer (Applied Biosystems), $0.5 \mathrm{U}$ AmpliTaq DNA polymerase (Applied Biosystems). PCR conditions were as follows: 25 and 30 cycles, respectively, with $94^{\circ} \mathrm{C}$ for $30 \mathrm{~s}, 56^{\circ} \mathrm{C}$ for $1 \mathrm{~min}, 72^{\circ} \mathrm{C}$ for $1 \mathrm{~min}$. The samples with the most evenly amplified smear from the 25- and 30-cycle PCRs were pooled and used for the library construction.
Pooled PCR products were hybridized with 100 pmol of a mixture of biotinylated oligonucleotides probes $\left((\mathrm{AG})_{21},(\mathrm{ATT})_{6},(\mathrm{AT})_{7},(\mathrm{AAG})_{8}\right.$ and $(\text { AAAT) })_{7}$ ) in a total volume of $100 \mu \mathrm{l}$ of SSC/SDS buffer. Streptavidin-coated beads (Roche) were then added and incubated at room temperature to capture DNA fragments with microsatellite sequences complementary to the oligonucleotide probes. Beads and attached probes were separated magnetically from the supernatant using a Magnetic Particle Separator (Roche). Following three soft and three hard stringency washes, the bound DNA was recovered by incubating in $1 \mathrm{M}$ TrisHCL $0.5 \mathrm{M}$ EDTA at $95^{\circ} \mathrm{C}$ for $5 \mathrm{~min}$.

The TOPO TA Cloning Kit (Invitrogen) was used to clone fragments according to the manufacturer's instructions. Colonies with inserts were identified by white colour and suspended in $150 \mu \mathrm{l}$ distilled water and heated at $95^{\circ} \mathrm{C}$ for $3 \mathrm{~min}$. When analyzing the white colonies by PCR, the following conditions were used: $0.4 \mu \mathrm{M}$ forward primer (5'-TGTAAAACGACGGCCAGT-3'), $0.4 \mu \mathrm{M}$ reverse primer (5'-CAGGAAACAGCTATGACC-3'), $1.5 \mathrm{mMMgCl}_{2}, 0.125 \mathrm{mM}$ dNTPs, $1 \times$ polymerase buffer (Applied Biosystems), 0.5 U AmpliTaq DNA polymerase (Applied Biosystems), $2 \mu$ l template in a final volume of $25 \mu \mathrm{l}$. The PCR conditions were as follows: 35 cycles with $94^{\circ} \mathrm{C}$ for $30 \mathrm{~s}, 50^{\circ} \mathrm{C}$ for $1 \mathrm{~min}$, $72^{\circ} \mathrm{C}$ for $1 \mathrm{~min}$. The PCR products were subsequently precipitated and diluted in $10 \mu \mathrm{lddH} 2 \mathrm{O}$. The PCR product $(2 \mu \mathrm{l})$ was used as template DNA in a sequencing reaction using the BigDye Terminator version 1.1 Cycle Sequencing Kit (Applied Biosystems) together with the forward primer. The sequencing program was set as follows: 25 cycles with $96^{\circ} \mathrm{C}$ for $10 \mathrm{~s}, 50^{\circ} \mathrm{C}$ for $5 \mathrm{~s}, 60^{\circ} \mathrm{C}$ for $4 \mathrm{~min}$. Precipitated products were sequenced on an ABI PRISM 3100 genetic analyser (Applied Biosystems).

Nineteen inserts were sequenced and five unique direpeat microsatellite motifs were detected, in addition to a few monorepeats. Primer pairs were possible to design for four of the five direpeat loci using the program Primer 3 (v. 0.4.0) (Rozen \& Skaletsky 2000) and three of them amplified a product of expected length and were interpreted as polymorphic in four test individuals. The repeat motif in the cloned sequence was $(\mathrm{CT})_{9}$ for Lsa127, (GT) 6 for Lsa158 and (TG) 18 for Lsa165. The position of all three loci in the zebra finch genome was determined by BLAST analyses following Dawson et al. (2007) and is given in Table 1. 


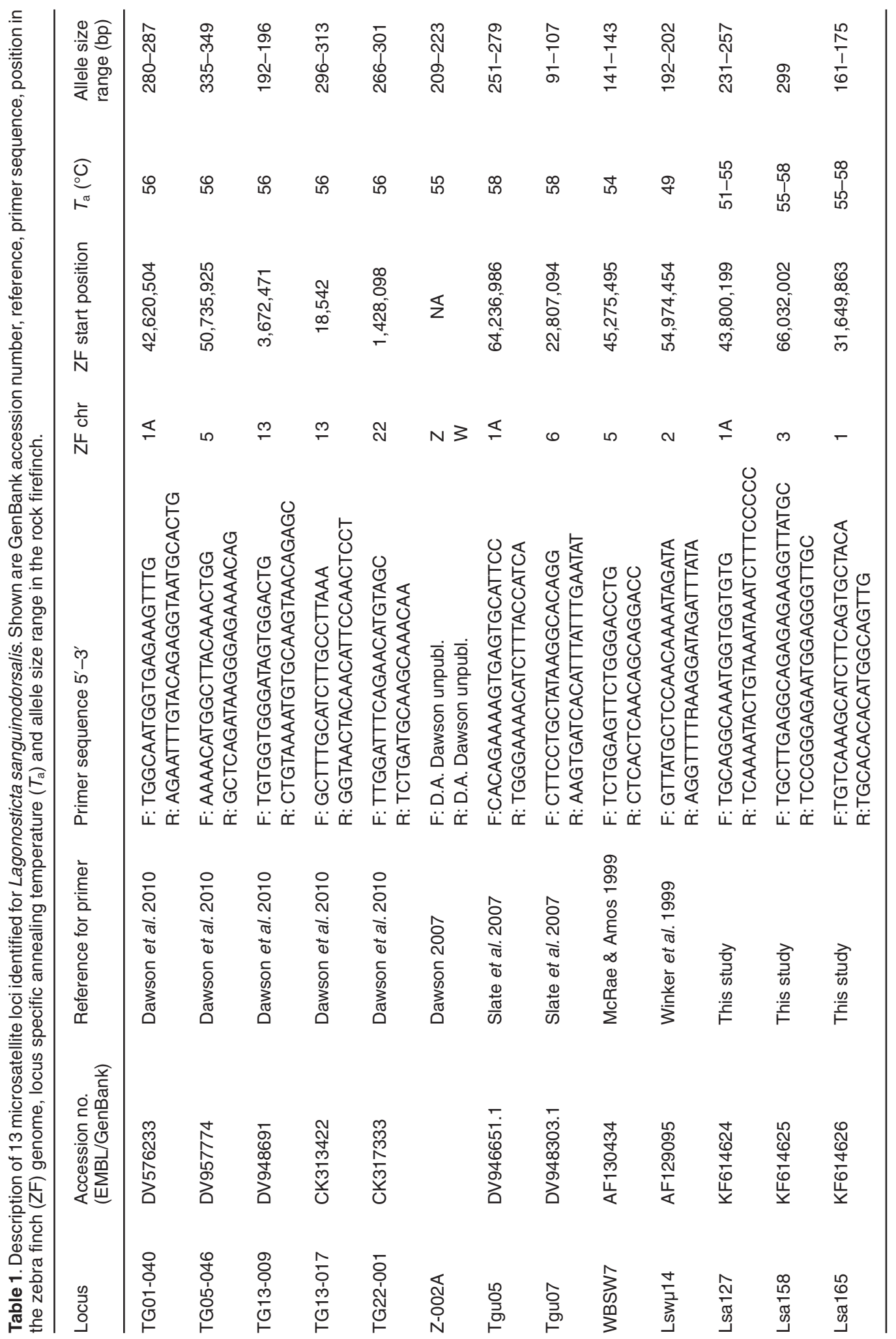




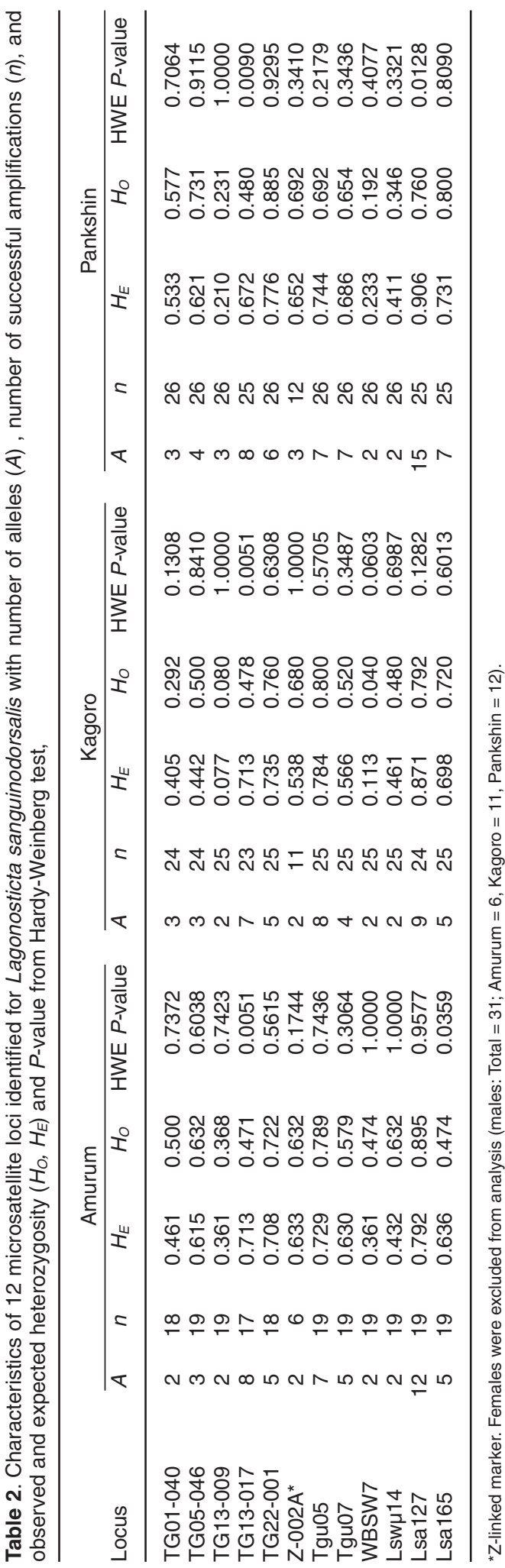

The variability of the 13 successful loci were further tested in 70 individuals from three rock firefinch populations: Amurum $(n=19)$, Pankshin $\left(n=26 ; 09^{\circ} 21^{\prime} 36.23^{\prime \prime} \mathrm{N}, 09^{\circ} 25^{\prime} 52.67^{\prime \prime} \mathrm{E}\right)$ and Kagoro $\left(n=25 ; 09^{\circ} 34^{\prime} 27.20^{\prime \prime} \mathrm{N}, 08^{\circ} 22^{\prime} 54.39^{\prime \prime} \mathrm{E}\right)$. The PCRmix contained $1 \times \mathrm{Q}$-mix (Qiagen), $1.2 \mathrm{pmol}$ $(0.2 \mu \mathrm{M})$ each of forward and reverse primer, $10-25 \mathrm{ng}$ DNA template in a $6 \mu \mathrm{l}$ reaction volume. The PCRs were initiated with a hotstart $\left(95^{\circ} \mathrm{C}\right.$ for $15 \mathrm{~min}$ ) followed by seven touchdown cycles with $94^{\circ} \mathrm{C}$ for $30 \mathrm{~s}, T_{a}$ for $30 \mathrm{~s}$ (start $T_{a}$ depended on the locus; see Table 1 ) with $0.5^{\circ} \mathrm{C}$ reduction per cycle, and $72^{\circ} \mathrm{C}$ for $30 \mathrm{~s}$. The touchdown was followed by 30 cycles with $94^{\circ} \mathrm{C}$ for $30 \mathrm{~s}, T_{a}$ minus 3 to $4^{\circ} \mathrm{C}$ for $90 \mathrm{~s}$ and $72^{\circ} \mathrm{C}$ for $90 \mathrm{~s}$; and a final extension at $72^{\circ} \mathrm{C}$ for $10 \mathrm{~min}$. PCR products were separated in an ABI PRISM 3730 capillary sequencer (Applied Biosystems).

The results showed that locus Lsa158 which was initially interpreted as polymorphic in the four test individuals was apparently monomorphic in the rock firefinch. Among the 12 polymorphic loci, the number of alleles ranged between 2 and 15 in the different populations (Table 2). Expected heterozygosity ranged between 0.36 and 0.79 in the Amurum population, 0.08 and 0.87 in the Kagoro population, and 0.21 and 0.91 in the Pankshin population (Table 2). Estimation of null allele frequencies implemented in MICROCHECKER version 2.2.3 (Oosterhout et al. 2004) showed presence of null alleles in TG13-017 for all three populations (ranging from 15-16\%) and in Lsa127 for one population (Pankshin; 8\%); and these two loci deviated from Hardy-Weinberg equilibrium before (but not after) Bonferroni correction in at least one population (Table 2) using tests implemented in FSTAT version 2.9 (Table 2; Goudet 2001). Z-002A is a Z- and W-linked microsatellite marker that has been used successfully for molecular sexing in several bird species (Dawson 2007). In the rock firefinch, the Z-linked locus was found to be polymorphic with two alleles in 6 and 11 tested males in the Amurum and Kagoro populations respectively, and with three alleles in the 12 tested males in Pankshin population. In addition, genotyping of a few adult male and female rock firefinches - adult birds are easily sexed due to the species' pronounced sexual plumage dimorphism (Fry \& Keith 2004) - confirmed amplification of both the Z- and the $\mathrm{W}$-fragments, and since the $\mathrm{W}$-fragment was shorter than all three Z-alleles this primer pair provides a means to sex rock firefinches before 
Table 3. Cross-amplification success in five finch species ( $n=$ number of tested individuals). Number of alleles amplified and no amplification (NA) are indicated.

\begin{tabular}{|c|c|c|c|c|c|}
\hline Locus & $\begin{array}{c}\text { Lagonosticta } \\
\text { rara } \\
(n=1)\end{array}$ & $\begin{array}{l}\text { Lagonosticta } \\
\text { senegala } \\
(n=18)\end{array}$ & $\begin{array}{c}\text { Euschistospiza } \\
\text { dybowskii } \\
(n=2)\end{array}$ & $\begin{array}{l}\text { Vidua maryae } \\
\qquad(n=5)\end{array}$ & $\begin{array}{l}\text { Vidua chalybeata } \\
\qquad(n=2)\end{array}$ \\
\hline TG01-040 & 1 & 1 & 1 & 5 & 2 \\
\hline TG05-046 & 2 & 6 & 2 & 1 & 1 \\
\hline TG13-009 & 1 & 2 & 1 & 2 & 1 \\
\hline TG13-017 & 1 & 10 & 2 & 5 & 2 \\
\hline TG22-001 & 1 & 5 & 2 & 1 & 1 \\
\hline Z-002A & 2 & 2 & 3 & 2 & 1 \\
\hline TG005 & 1 & 9 & 2 & 3 & 3 \\
\hline TG007 & 1 & 4 & 1 & 1 & 1 \\
\hline WBSW7 & 1 & 1 & 1 & 5 & 1 \\
\hline Lswu14 & 1 & 1 & 1 & 2 & NA \\
\hline Lsa127 & 2 & 2 & 3 & 2 & NA \\
\hline Lsa158 & 1 & 4 & 1 & 1 & 1 \\
\hline Lsa165 & 2 & 2 & 2 & 2 & 2 \\
\hline
\end{tabular}

they are displaying their sex-specific plumage.

Finally, we tested the set of 13 primer pairs in five closely related African Estrildidae and Viduidae finches: two other Lagonosticta species (L. rara and L. senegala), one other Estrildidae finch (Euschistospiza dybowskii) and two Viduidae finches (Vidua chalybeata and V. maryae; Sorenson et al. 2004). The cross-species amplification was highly successful and all loci, except Lsw $\mu 14$ and Lsa127 in $V$. chalybeata, amplified with varying levels of polymorphism (Table 3). Interestingly, Lsa158, which was monomorphic in the rock firefinch, was polymorphic (four alleles) in L. senegala. In three of the species, we tested only one or two individuals (Table 3 ) and we expect the degree of polymorphism to increase when more individuals and populations are evaluated.

Many species are experiencing fragmentation of their populations as a result of the impact of human activities on their habitat (WCMC 1992). Habitat fragmentation leads to an overall reduction in population size and reduced gene flow among patches (Frankham et al. 2002). Genetic diversity can be easily lost in smaller populations, which is unfortunate since it constitutes the raw material for evolutionary change and thus the potential to adapt to changing environments. Loss of genetic diversity can jeopardize the long-term survival prospects of populations due to negative inbreeding effects and even lead to extinction in the event of environmental change (Frankham et al. 2002). Thus, understanding and maintaining genetic diversity is of primary concern in conservation biology. The availability of microsatellite markers for the rock firefinch and some related species brings us a step closer to evaluating its genetic status and population genetic structure.

We conclude that our work has detected a set of highly useful microsatellite markers for population genetic research in the rock firefinch and closely related Estrildidae and Viduidae finches.

We would like to thank A.P. Leventis Ornithological Research Institute APLORI, Laminga, Nigeria for logistic support for fieldwork (sample collection). This project was funded by A.P. Leventis Foundation, Swedish Ornithological Society and the Swedish Research Council. Arin Izang was a valuable assistant during the fieldwork. This research was carried out in collaboration with the A.P. Leventis Ornithological Research Institute, Laminga, Nigeria.

\section{REFERENCES}

ABALAKA, J.I. \& JONES, P.J. 2011. Population densities of the rock firefinch Lagonosticta sanguinodorsalis and some other estrildine and viduine finches on the Jos Plateau, Nigeria. In: Proceedings of the 12th Pan African Ornithological Congress, 2008, (eds) D.M. Harebottle, A.J.F.K. Craig, M.D. Anderson, H. Rakotomanana \& M. Muchai, pp. 131-134. Animal Demography Unit, Cape Town, South Africa.

BENSCH, S., HASSELQUIST, D. \& VON SCHANTZ, T. 1994. Genetic similarity between parents predicts hatching failure: nonincestuous inbreeding in the great reed warbler. Evolution 48: 317-326.

BRANDT, M. \& CRESSWELL, W. 2008. Breeding behaviour, home range and habitat selection in rock 
firefinches Lagonosticta sanguinodorsalis in the wet and dry season in central Nigeria. Ibis 150: 495-507.

DAWSON, D.A. 2007. Genomic analysis of passerine birds using conserved microsatellite loci. Ph.D. thesis, University of Sheffield, Sheffield, U.K.

DAWSON, D.A., ÅKESSON, M., BURKE, T., PEMBERTON, J.M., SLATE, J. \& HANSSON, B. 2007. Gene order and recombination in homologous regions of the chicken and a passerine bird. Molecular Biology and Evolution 24: 1537-1552.

DAWSON, D.A., HORSBURGH, G.J., KUPPER, C., STEWART, I.R.K., BALL, A.D., DURRANT, K.L., HANSSON, B., BACON, I., BIRD, S., KLEIN, A., KRUPA, A.P., LEE, J.W., MARTIN-GALVEZ, D., SIMEONI, M., SMITH, G., SPURGIN, L.G. \& BURKE, T. 2010. New methods to identify conserved microsatellite loci and develop primer sets of high crossspecies utility - as demonstrated for birds. Molecular Ecology Resources 10: 475-494.

ELLEGREN, H. 2004. Microsatellites: simple sequences with complex evolution. Nature Reviews Genetics 5: 435-445.

FRANKHAM, R., BRISCOE, D.A. \& BALLOU, J.D. 2002. Introduction to Conservation Genetics. University of Cambridge Press, Cambridge, U.K.

FRY, C.N. \& KEITH, S. (eds) 2004. Birds of Africa, Vol. VII. Christopher Helm, London, U.K.

GOUDET, J. 2001. FSTAT, a program to estimate and test gene diversities and fixation indices, version 2.9.3. Online at: http://www2.unil.ch/popgen/softwares/ fstat.htm

LANDGUTH, E.L., FEDY, B.C., OYLER-McCANCE, S. J., GAREY, A.L., EMEL, S.L., MUMMA, M., WAGNER, H.H., FORTIN, M-J. \& CUSHMAN, S.A. 2012. Effects of sample size, number of markers, and allelic richness on the detection of spatial genetic pattern. Molecular Ecology Resources 12: 276-284.

McRAE, S.B. \& AMOS, W. 1999. Characterization of hypervariable microsatellites in the cooperatively breeding white-browed sparrow weaver Plocepasser mahali. Molecular Ecology 8: 903-904.

MILLS, M.S.L. 2010. Rock firefinch Lagonosticta sanguinodorsalis and its brood parasite, Jos Plateau indigobird Vidua maryae, in northern Cameroon. Bulletin of the African Bird Club 17: 86-89.

NORDSTRÖM, S. \& HEDREN, M. 2007. Development of polymorphic nuclear microsatellite markers for polyploid and diploid members of the orchid genus Dactylorhiza. Molecular Ecology Resources 7: 644-647.

OLANO-MARIN, J., DAWSON D.A., GIRG, A., HANSSON, B., LJUNGQVIST, M., KEMPENAERS, B. \& MUELLER, J.C. 2010. A genome-wide set of 106 microsatellite markers for the blue tit (Cyanistes caeruleus). Molecular Ecology Resources 10: 516-532.

OOSTERHOUT, C.V., HUTCHINSON, W.F., WILLS, D.P.M. \& SHIPLEY, P. 2004. Micro-Checker: software for identifying and correcting genotyping errors in microsatellite data. Molecular Ecology Notes 4: 535-538.

PAYNE, R.B. 1998. A new species of firefinch Lagonosticta from northern Nigeria and its association with the Jos Plateau indigobird Vidua maryae. Ibis 140: 368-381.

ROZEN, S. \& SKALETSKY, H. 2000. Primer 3 on the WWW for general users and for biologist programmers. Methods in Molecular Biology 132: 365-386.

SALMONA, J., DAWSON, D.A., FOUILLOT, D., GHESTEMME, T., THEBAUD, C., CHIKHI, L. \& SALAMOLARD, M. 2010. The utility of existing passerine microsatellite markers for genetic studies in endangered species: as demonstrated for a critically endangered forest bird endemic to Réunion Island, the Réunion cuckoo-shrike (Coracina newtoni). Conservation Genetics Resources 2: 361-364.

SIMEONI, M., DAWSON, D.A., ROSS, D.J., CHALINE, N., BURKE, T. \& HATCHWELL, B.J. 2007. Characterisation of 20 microsatelite loci in the long-tailed tit Aegithalos caudatus (Aegithalidae, AVES). Molecular Ecology Notes 7: 1319-1322.

SLATE, J., HALE, M.C. \& BIRKHEAD, T.R. 2007. Simple sequence repeats in zebra finch (Taeniopygia guttata) expressed sequence tags: a new resource for evolutionary genetic studies of passerines. BMC Genomics 8: 52.

SORENSON, M.D., BALAKRISHNAN, C.N. \& PAYNE, R.B. 2004. Clade-limited colonization in brood parasitic finches (Vidua spp.). Systematic Biology 53: 140-153.

TAKEZAKI, N. \& NEI, M. 1996. Genetic distances and reconstruction of phylogenetic trees from microsatellite data. Genetics 144: 389-399.

WCMC. 1992. Global Biodiversity: Status of the Earth's Living Resources. Chapman \& Hall, London.

WINKER, K., GLENN, T.C. \& GRAVES, G.R. 1999. Dinucleotide microsatellite loci in a migratory wood warbler (Parulidae: Limnothlypis swainsonii) and amplification among other songbirds. Molecular Ecology 8: 1553-1556.

WRIGHT, D. \& JONES, P. 2005. Population densities and habitat associations of the range-restricted rock firefinch Lagonosticta sanguinodorsalis on the Jos Plateau, Nigeria. Bird Conservation International 15: 287-295.

ZANE, L., BARGELLONI, L. \& PATARNELLO, T. 2002. Strategies for microsatellite isolation: a review. Molecular Ecology 11: 1-16.

Responsible Subject Editor: S. Willows-Munro 